\title{
Status and trends of Gull-billed Tern Gelochelidon nilotica in Europe and Africa
}

\author{
J. M. SÁNCHEZ, A. MUÑOZ DEL VIEJO, C. CORBACHO, E. COSTILlO \\ and C. FUENTES
}

\section{Summary}

Gull-billed Tern Gelochelidon nilotica is classed as Endangered in Europe (Tucker and Heath 1994, Hagemeijer and Blair, 1997), but there have been no detailed studies of the trends in the different populations occurring in Europe and Africa. Here we study the status and trends of the species in Europe and north and north-east Africa. We estimate the total population at 10,500-12,900 breeding pairs, and recognize two biogeographical populations in this region. The western population, comprising colonies in northern Europe (Denmark, Netherlands, Germany), France, Italy, Spain, and north and north-east Africa, consists of at most 6,200 pairs, 1,800 of which are in African colonies. The eastern population, comprising colonies in the Balkan Peninsula, Greece, shores of the Black Sea and Sea of Azov, and Turkey, consists of at most 6,80o pairs. Two trends were observed: a first phase from 1900 up to the mid-1970s in which the northern European populations practically disappeared; and a second phase of stabilization, or even increase, in some of the western colonies, while the eastern population continued to decline. There is a marked concentration of the species in just a few localities in the countries of the Mediterranean basin.

\section{Introduction}

Gull-billed Tern Gelochelidon nilotica has a cosmopolitan distribution, occurring in all biogeographical areas. Six subspecies are recognized, that occurring in Europe and Africa being nominate G. n. nilotica. Unlike some of the subspecies, the nominate inhabits both brackish-water (Sánchez 1984) and freshwater areas (Møller 1977, Sánchez and Sánchez 1991).

Population studies (Møller 1975b, Biber 1993, Tucker and Heath 1994) have shown a strong, although unquantified, declining trend from the beginning of the twentieth century, so that the currently active colonies represent only a small fraction of those that existed then (Møller 1975a). Current estimates of the Palaearctic population vary markedly from author to author (Biber 1993, Tucker and Heath 1994, Rose and Scott 1994, 1997, Hagemeijer and Blair 1997, Wetlands International 2002): that there exists no reliable estimate is due to the lack of coordinated censuses over recent decades and the very different values reported for the same regions. Indeed, for a species such as this, which occupies highly unstable and unpredictable habitats, such coordination of the information is essential (Møller 1975a, b, Sánchez and Blasco 1987, Cabo and Sánchez 1984, Foschi 1986, Biber 1993, Sadoul and Isenmann 1999).

While there has been some interest recently in the status of the different biogeographical populations (Rose and Scott 1994, 1997, UICN 1994, Wetlands 
International 2002), in most cases the data used to catalogue the species have been disjointed, taken from different years in different regions, with either no information on large breeding areas or with wide ranges in the corresponding estimates. This study attempts to evaluate current trends in the different regions where the species breeds, and to estimate the size of the Palaearctic population, by compiling available data on its breeding from the middle of the twentieth century onwards.

\section{Material and methods}

The data used to evaluate the breeding population are a compilation of all the data published in the second half of the twentieth century on the species' breeding in Europe and north and north-east Africa (see Appendix), together with new data on breeding in the Iberian Peninsula. To establish the extent of its presence (UICN 1994), we used the convex minimal polygons corresponding to the species (White and Garrot 1990): the coordinates of all the colonies were put into a Geographical Information Systems database (Arc-Info), and the land surface area under the polygon was computed. Ringing recovery data were also taken from published studies (Møller 1975e), together with unpublished data on the Spanish populations (Centro de Migración de Aves, Ministerio de Medio Ambiente, Spain). The wintering data for the species on the continent of Africa were taken from coordinated censuses of the IWRB and Wetlands International carried out in the period 1991-1997 (Rose 1992, Perennou 1992, Rose and Taylor 1993, Dodman and Taylor 1995, 1996, Dodman et al. 1997, Delany et al. 1999). We use the terms "places" and "locality" (UICN 1994) in the sense of geographical areas and site colony, respectively.

Spearman's correlation coefficients (Sadoul et al. 1996) were used to study the relationships between different areas, localities or colonies. Frequency distributions were compared using a chi-squared test, and the percentage test was used to study relative variations in different periods. All calculations were performed using the program STATISTICA.

\section{Results}

\section{Biogeographical population}

There are few published data on ringed bird recoveries (Figure 1), but those there are suggest the existence of a possible biogeographical unit since they show movement through the western countries of Europe and of trans-Saharan Africa (Mauritania and Senegal), thereby indicating that in Europe there might be one western biogeographical population and another eastern. The former would consist of the European populations up to the eastern borders of Germany and Austria and Italy, and to the south include Morocco, Mauritania and Senegal (Figure 1), although there has been no confirmation of interchange of individuals between European and African colonies. The eastern biogeographical population would consist of the populations of the Balkan Peninsula, the Black Sea and Turkey.

Active European colonies declined in the twentieth century (Figure 1). The species has practically disappeared from north and central Europe (Table 1, 


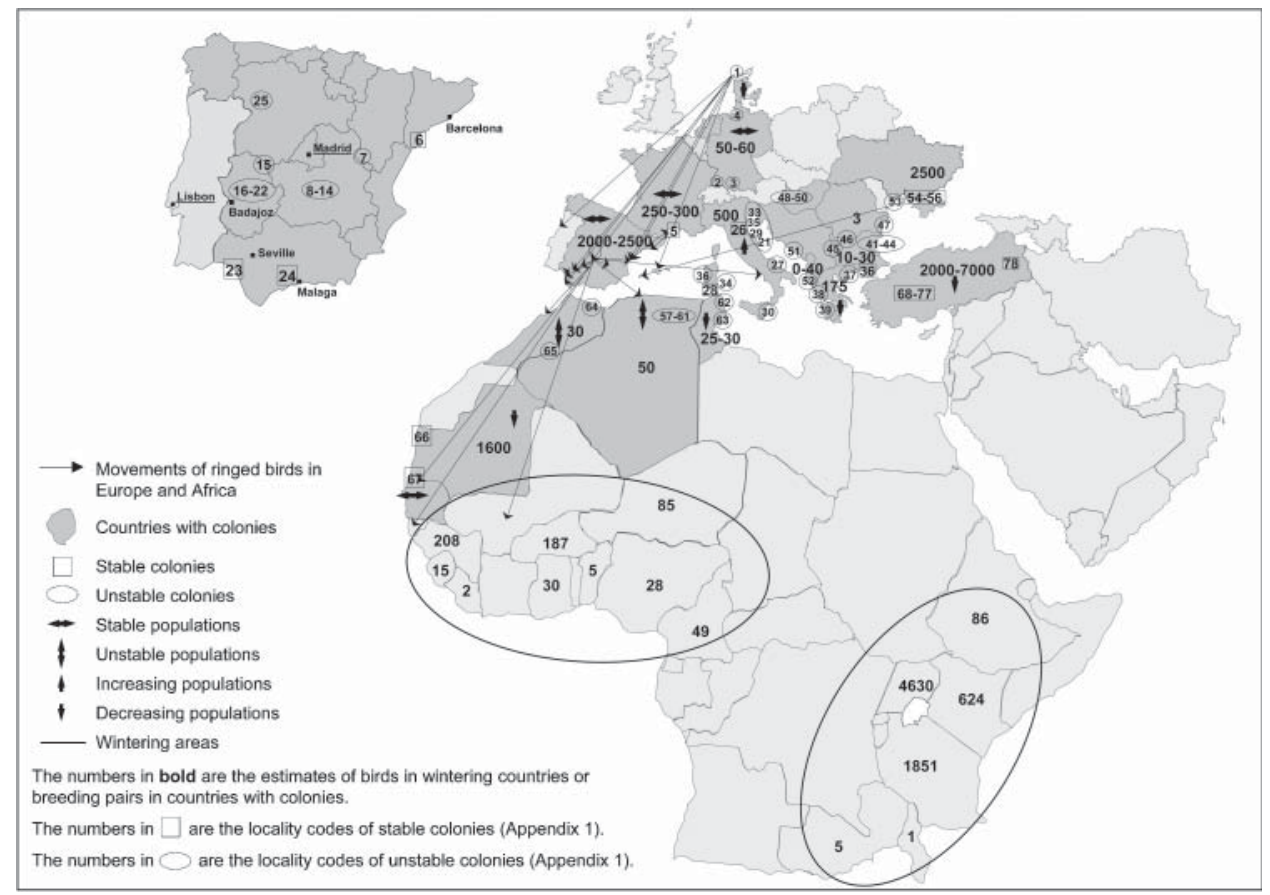

Figure 1. Wintering and breeding areas of Gull-billed Tern in Europe and Africa.

Appendix), as well as from most of the Balkan Peninsula (Keve 1960, Biber 1993), where its occurrence is irregular both in number of pairs and in temporal continuity. This could explain the existence of two areas of presence (UICN 1994; convex minimal polygons, Figure 1 ). These two regions are represented by two western polygons (western European and African) that would presumably be connected by the aforementioned migrants, and an eastern polygon. The (land) area of presence represented by these polygons is $616,843 \mathrm{~km}^{2}, 336,954 \mathrm{~km}^{2}$ and $72,010 \mathrm{~km}^{2}$ in the eastern, western and African polygons, respectively (Figure 1 ). The potential breeding areas for the species are undoubtedly only a very small fraction of these polygons.

Winter censuses show that the wintering grounds lie in steppe and savannah south of the North African deserts between $20^{\circ} \mathrm{N}$ and the Equator (Table 2). They show two segregated areas, one in the western region (Table 2 ) with a very small population $(650 \pm 372$ birds, range $440-1,137)$. Most of this wintering population is restricted to Senegal and Mali (Table 2), with numbers that are far higher $(6,446 \pm 5,547$ birds, range 1,024-14,580). The greatest concentrations are found in Uganda, Tanzania and Kenya. The wintering population in southern African countries is almost nil (Table 2).

\section{Evaluation of the population}

The species bred in 88 places and 100 localities in the second half of the twentieth century (Table 1, Figure 1, Appendix), mostly concentrated in the Mediterranean 


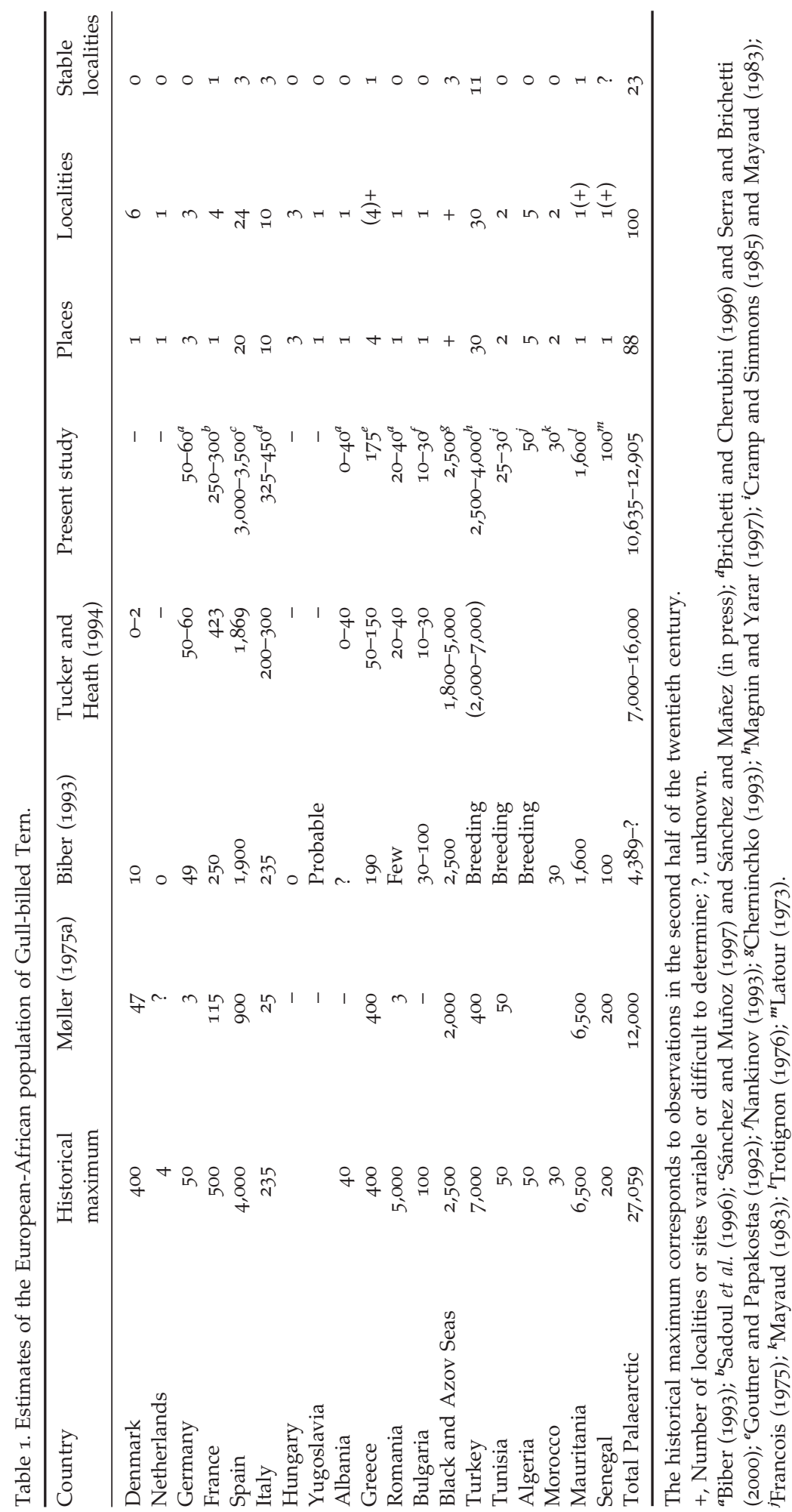


Table 2. Results of the Gull-billed Tern census in wintering areas.

\begin{tabular}{|c|c|c|c|c|c|}
\hline Country & Area & Average & Max. & Min. & SD \\
\hline Benin & Western & 5 & 8 & 1 & 4.9 \\
\hline Burkina Faso & Western & $\mathrm{O}$ & o & o & \\
\hline Cameroon & Western & 49 & 142 & o & 64.8 \\
\hline Ivory Coast & Western & o & o & o & 0.0 \\
\hline Gabon & Western & o & o & $\mathrm{o}$ & \\
\hline Gambia & Western & 56 & 92 & 20 & 50.9 \\
\hline Ghana & Western & 30 & 30 & 30 & \\
\hline Guinea-Bissau & Western & 15 & 34 & o & 15.0 \\
\hline Mali & Western & 187 & 500 & o & 216.4 \\
\hline Mauritania & Western & 75 & 212 & 3 & 95.9 \\
\hline Niger & Western & 85 & 251 & 12 & 99.7 \\
\hline Nigeria & Western & 28 & 108 & $\mathrm{o}$ & 46.5 \\
\hline Senegal & Western & 208 & 679 & 11 & 271.3 \\
\hline Togo & Western & o & $\mathrm{o}$ & $\mathrm{o}$ & 0.0 \\
\hline Sierra Leone & Western & 2 & 3 & o & 2.1 \\
\hline Total & & 650 & 1,137 & 440 & 371.8 \\
\hline Burundi & Eastern & & & & \\
\hline Eritrea & Eastern & o & o & o & 0.0 \\
\hline Ethiopia & Eastern & 86 & 149 & 4 & 66.4 \\
\hline Kenya & Eastern & 624 & 1,485 & 121 & 534.6 \\
\hline Seychelles & Eastern & o & o & $\mathrm{o}$ & 0.0 \\
\hline Sudan & Eastern & o & o & $\mathrm{o}$ & 0.0 \\
\hline Tanzania & Eastern & 1,851 & 4,922 & o & $2,678.2$ \\
\hline Uganda & Eastern & 4,630 & 14,023 & 90 & $5,670.8$ \\
\hline Total & & 6,446 & 14,580 & 1,024 & $5,547.1$ \\
\hline Botswana & Southern & $\mathrm{O}$ & o & o & 0.0 \\
\hline Madagascar & Southern & o & o & $\mathrm{o}$ & 0.0 \\
\hline Malawi & Southern & 1 & 4 & $\mathrm{O}$ & 1.9 \\
\hline Mauritius & Southern & o & o & o & 0.0 \\
\hline Mozambique & Southern & o & o & $\mathrm{o}$ & 0.0 \\
\hline Namibia & Southern & o & o & o & 0.0 \\
\hline South Africa & Southern & o & o & $\mathrm{O}$ & 0.0 \\
\hline Swaziland & Southern & o & o & o & 0.0 \\
\hline Zambia & Southern & 5 & 15 & 1 & 6.0 \\
\hline Zimbabwe & Southern & $\mathrm{o}$ & $\mathrm{o}$ & $\mathrm{o}$ & 0.0 \\
\hline Total & & 6 & 15 & 1 & 5.9 \\
\hline
\end{tabular}

For sources see Material and Methods.

basin. It currently breeds stably in 23 localities - eight in the northern Mediterranean basin, 11 in Turkey and the rest in the Black Sea and Banc d'Arguin (see Appendix). Analysis of the data for the different presence polygons presented above shows that there exists only a single stable locality in the African polygon (Banc d'Arguin, Mauritania) where $94 \%$ of this region's population nest, and that there are seven stable localities in the western European polygon (Table 1 , Appendix) in which $75 \%$ (c. 3,200 pairs) of this biogeographical unit breed. In the eastern polygon, there are 15 stable localities, most of them in Turkey (11) supporting $90 \%$ (c. 6,300 pairs) of this population. 
Our estimate for the population is 10,500-12,900 pairs, with a maximum western population (western Europe, North Africa, Mauritania, and Senegal) of 6,200 pairs, of which 1,850 correspond to Africa. The eastern population is formed by a maximum of 6,800 pairs. The greater part of both populations breed in the Mediterranean (8,650 pairs, 67\%).

\section{Population trends}

The data show that the previously important populations of northern Europe and the Balkan Peninsula (Møller 1975d), underwent a sharp decline (Figure 2) over the course of the second half of the twentieth century, the trend being statistically significant $(r=-0.5448, n=77, P<0.0001$, and $r=-0.9440, n=5$, $P=0.016$, respectively), resulting in their practical disappearance. The situation was different in the Mediterranean basin populations, where in no case was

\section{Northern Europe}

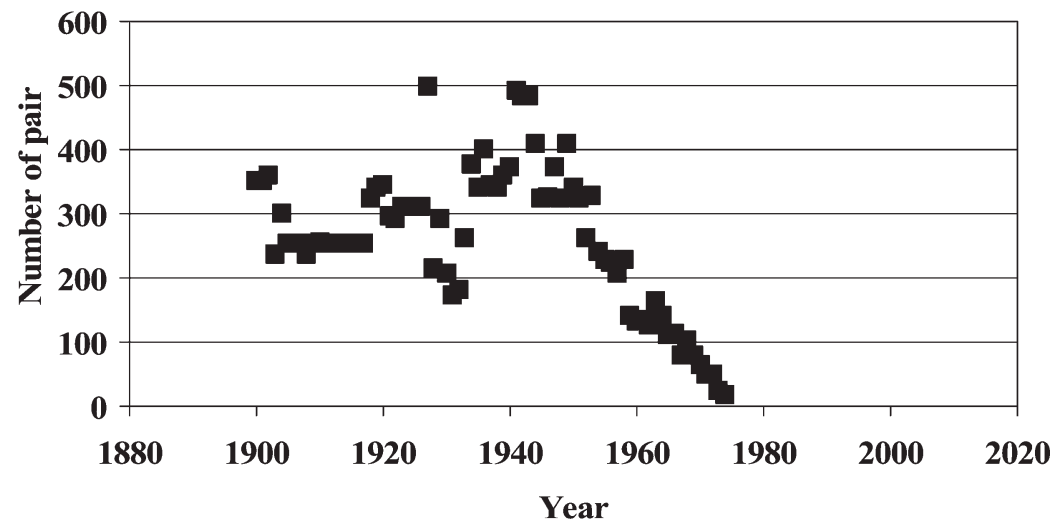

France

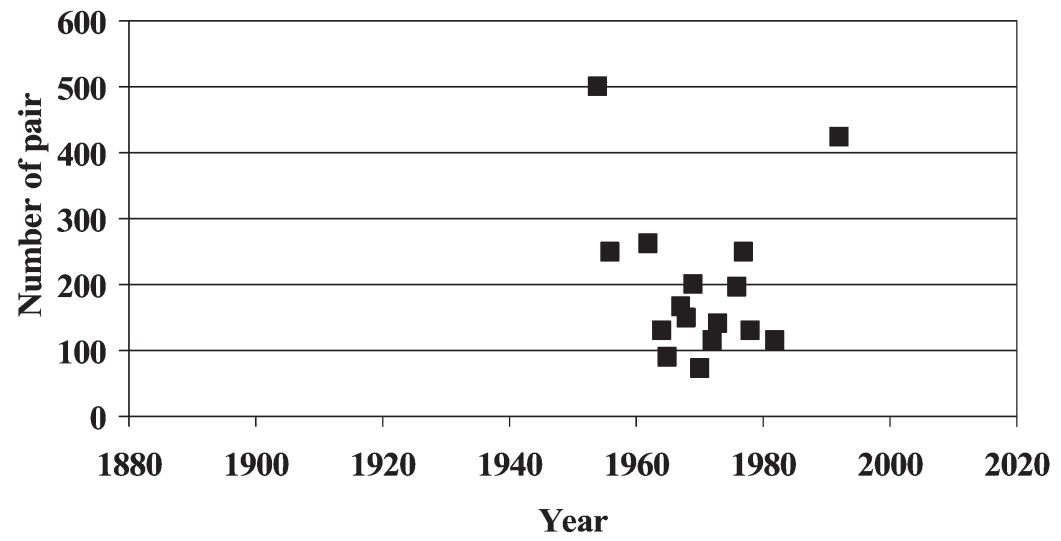

Figure 2. Trends in Gull-billed Tern populations of northern Europe (Denmark, Netherlands, Germany) and France. For sources see Appendix. 
a negative trend in the number of pairs observed (Figures 2, 3). In Italy, for instance, there was a significant increase in the overall population (Figure 3) as well as those of Comacchio and Sardinia (Figure 3). The French population in the Camargue showed a negative trend up to the mid-1970s, during which period there was a clear relationship with the corresponding observations in the colonies of The Netherlands $(r=0.6220, n=12, P=0.031)$. The apparent recovery after that date is not statistically significant. The data for the Iberian Peninsula populations are generally too sparse and at times temporally disjoint for any analysis of trends to be made, except for the clear increasing trend in population

Comacchio valley (Italy)

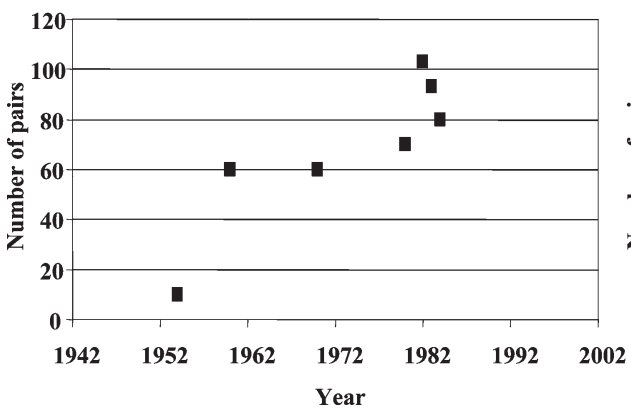

Sardinia inland (Italy)

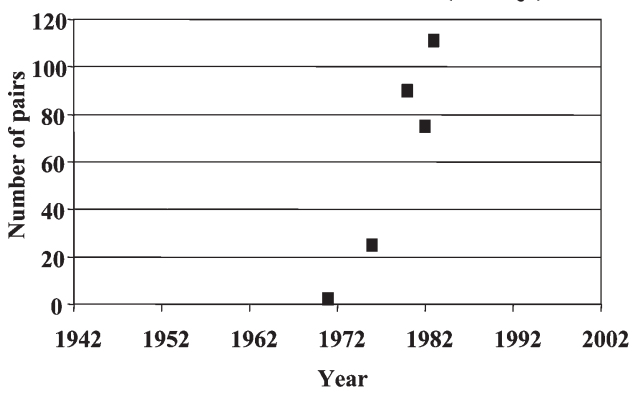

Fuentepiedra lagoon (Spain)

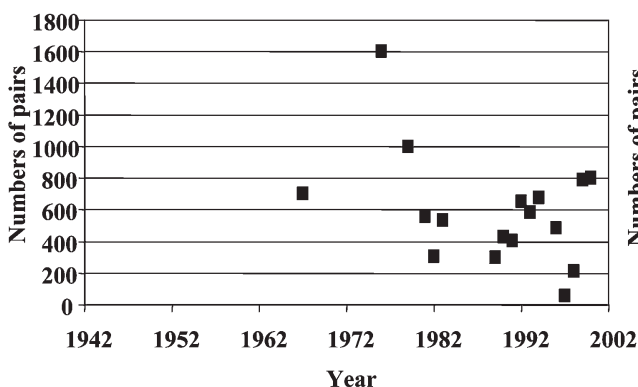

Manfredonia (Italy)

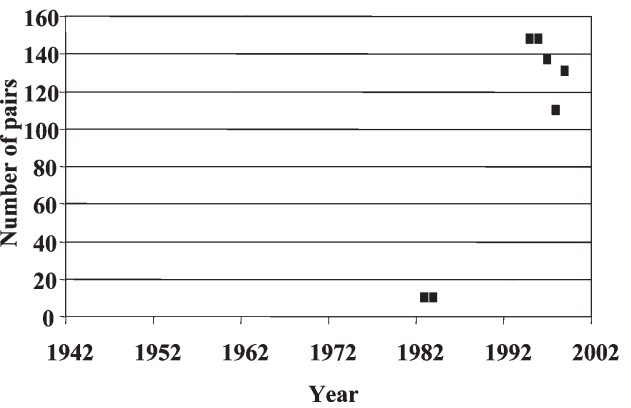

Ebro delta (Spain)

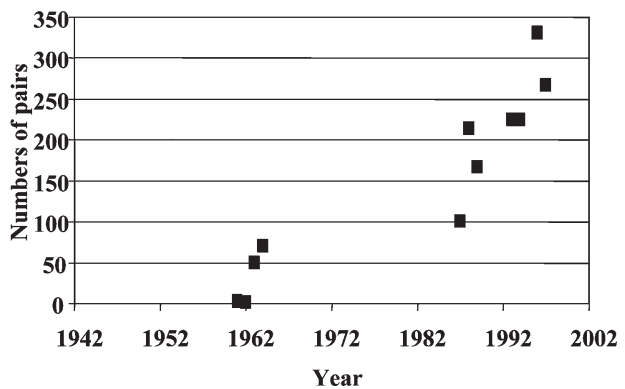

Doñana marshes (Spain)

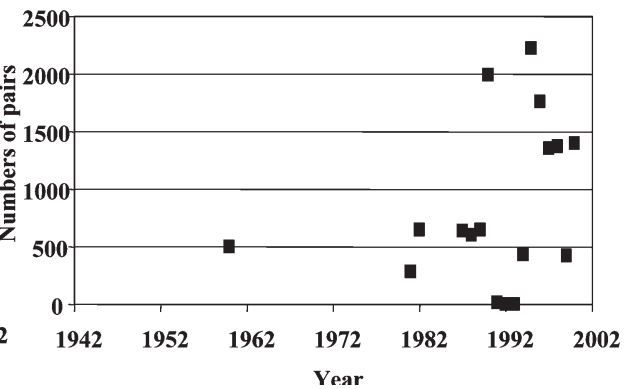

Figure 3. Trends in number of breeding pairs of Gull-billed Tern in the different stable localities of the western biogeographical population. For sources see Appendix. The Camargue is not represented here since its population is that of France shown in Figure 2. 
of the stable locality of the Ebro Delta $(r=0.9219, n=11, P<0.0001$; Figure 2$)$. Neither the apparent decreasing trend for the Fuentepiedra Lagoon nor the increasing trend for the Doñana Marshes (Figure 3) are statistically significant. No trend analysis is possible for other regions, again because of the sparseness of the data, but there seem to have been sharp declines in the populations of the Black Sea and Sea of Azov, Turkey and Banc d'Arguin.

Because of the aforementioned trends, the relative importance of these regions changed $\left(\chi^{2}=6,259, \chi_{0.05,3}^{2}=7.83\right)$ in the last quarter of the century, due mainly to the decline in nesting pairs in West Africa (from $63 \%$ to $13 \%$ of the total, $P<0.0001$ ) and the increase in importance in the Mediterranean region (from $18 \%$ to $67 \%$ of the total, $P<0.0001$ ). Comparing the maximum from the censuses in the second half of the twentieth century by country with the population size obtained in the present study (Table 2), we find that the breeding population has declined by at least $50 \%$ over that period.

\section{Discussion}

\section{Biogeographical delimitation}

Gull-billed Tern was once widely distributed over Europe and Africa, breeding in a great many places and localities (Møller 1975b). Currently, however, the number of places and localities has declined considerably. The results reported here show these populations to be highly fragmented, confirming the reports of previous workers (Møller 1975b, Cramp and Simmons 1985). The species has disappeared from large areas of Europe (northern Europe and most of the Balkan Peninsula for instance), leading to its concentration in the Mediterranean and Black Sea basins. This regression may be an expression of isolation between two areas of presence of the species (UICN 1994), areas which could be regarded as representing two biogeographical populations, as was suggested by Rose and Scott (1997) and Wetlands International (2002): one in Mediterranean countries of western Europe and some African localities (North Africa, Mauritania, Senegal), and the other consisting of colonies in Greece, the Black Sea basin and Turkey. This decline and fragmentation was reflected in a considerable decrease in the area of presence of the species. Wetlands International (2002) indicate both populations wintering in West Africa and East Africa (the Rift Valley and coast), but the wintering data could indicate a segregation of the wintering areas of the two subpopulations. The western population is represented by the western trans-Saharan countries, especially Mali and Senegal. One of the Gull-billed Tern's migration routes passes through Italy-Sicily, and the other, more usual, through the Strait of Gibraltar. The eastern population is represented by colonies in the countries bordering the Rift Valley, i.e. Uganda, Tanzania and Kenya. Its migration route passes through the Nile basin (Cramp and Simmons 1985). This two-populations hypothesis should be tested in further studies.

\section{Population size}

Møller (1975b) gave 12,000 pairs (24,000 individuals) as the biogeographical population, including that estimated for the entire western Palaearctic and North 
and East Africa. Biber (1993) estimated a minimum of 4,389 pairs for that same region. Subsequently, Rose and Scott (1994) gave 27,000-37,000 individuals for the populations of west Africa, western Europe, the Black Sea and the eastern Mediterranean, while Tucker and Heath (1994) give a population formed by 7,000-16,000 pairs (14,000-32,000 individuals), but their estimate excludes the African populations, and Wetlands International (2002) gave 24,000-55,000 individuals. Our estimate of the European and African population is 10,60013,000 pairs (21,000-26,000 individuals). While this number is close to that of Møller (1975b), it is necessary to note that at least the population of Turkey seems to be clearly underestimated in Møller (400 pairs), as possibly also is that of the Black Sea; both regions are indicated as being areas of sharp population decline (Sánchez and Fasola, 2002), and currently possess 5,000-6,500 pairs. The case is similar for Biber's estimate (1993), in which there are no quantitative data for Turkey and North Africa, except Morocco, even though these are regions that support 4,500-6,500 pairs. In general, however, all the estimates made in the second half of the twentieth century (Table 1 ) point to four regions with major populations: the Iberian Peninsula, Black Sea, Turkey and Banc d'Arguin (Mauritania).

If, as seems to be indicated by the admittedly sparse ringing recovery data, and as suggested by Rose and Scott (1994) and Wetlands International (2002), there are indeed two biogeographically separated populations (western and eastern), then the western population would be estimated at 5,430-6,150 pairs $(3,000-3,500$ of them in the Iberian Peninsula), and the eastern would be $5,205-6,785$ pairs $(5,000-6,500$ of them in Turkey and the Black Sea basin). For the reasons noted above, it is not easy to compare these values with those reported by some other workers (Møller 1975a, b, Biber 1993, Tucker and Heath 1994), but Wetlands International (2002) obtained similar sizes, at least for the minimum values.

\section{Population trends}

While the temporal heterogeneity of the data make it complicated to evaluate the magnitude of the trends, some aspects seem to be evident. There are currently fewer nesting localities than historically (see Møller 1975a), and indeed several workers have noted sharp declines in many areas (Cherninchko 1993, Siokhin 1993, Biber 1993, Tucker and Heath 1994). If we correct Møller's (1975b) data by assuming that, historically, at least as many pairs bred in Turkey and the Black Sea as do today, we find that there would have been at least a $20-30 \%$ decline (from 14,600-16,100 pairs to 10,635-12,905) over the last 25 years in the western Palaearctic population. While this is a conservative estimate, the real decline, however, was probably even greater. The decline in the breeding population is conditioned by the sharp decrease that occurred up to the 1970s, a decrease which seemed to affect all the populations given the correlations found between some of them (e.g. northern Europe and France).

From the 1970s onwards, the eastern populations of the Black Sea and Turkey seem to continue with the same trend (Cherninchko 1993, Siokhin 1993, Biber 1993, Tucker and Heath 1994, Rudenko 1996), and a similar situation is observed in the Banc d'Arguin population (Mauritania) (Møller 1975b, Biber 1993, Tucker 
and Heath 1994), which shows a decline of more than 70\%. Therefore the reason that the overall population did not fall by more than was noted above has to be sought in the recovery of the western Mediterranean populations, these being the only ones that not only are not presently declining but in some cases are increasing. The Italian populations (Foschi 1986, Fasola et al. 1993, Brichetti and Cherubini 1996, 1997) show a positive trend overall, as does the population of the Camargue (Sadoul et al. 1996, Sadoul and Isenmann 1999). In both areas together, there are 1,000 breeding pairs (20-25\% of the western population). The area with the greatest increase is, however, undoubtedly the Iberian Peninsula, where the population has quadrupled in the last quarter of a century. This was a consequence of the increase in the Ebro Delta population (Sánchez and Mañez in press), the relative maintenance of the other two stable populations (Doñana Marshes and Fuentepiedra Lagoon, both in southern Spain) and the spectacular growth of populations in new areas such as Extremadura (western Spain) where the population has grown by a factor of 10 in the last decade (Sánchez and Sánchez 1991) to the current 1,100 pairs (Sánchez and Mañez in press). Finally, although the sparse data on the Mediterranean populations of North Africa do not allow any trend to be deduced, these populations do seem to be highly unstable in numbers and breeding sites (Robin 1968, Francois 1975, Cabo and Sánchez 1984, Sánchez and Fasola, 2002).

Overall, the population appears to be concentrated in the countries of the Mediterranean basin ( $67 \%$ of the total), although there is a declining trend in the eastern region offset by an increasing trend in the western. Perhaps the greatest danger in these trends is the concentration of most of the pairs into just a few areas: $75 \%$ of the population of the entire Palaearctic is found in just 22 localities that can be regarded as stable. The rest exhibit erratic nesting over various wet zones of the study area: in the western biogeographical population, there exist only eight stable zones, with the remainder corresponding to localities in Greece (1), Turkey (11) and the Black Sea (3), all in regions presenting a strong declining trend.

\section{Causes of the trends}

Many varied factors have been identified as causes of impacts on the populations in the different regions where Gull-billed Tern has bred or is breeding. One factor of major importance is a consequence of its highly unstable breeding habitat (Møller 1975b, d, Sánchez and Muñoz 1997, Sánchez, 2003): clutches are often lost by rising water-levels inundating the colony, or falling water-levels connecting the islets on which the species nests to the shore (Sánchez and Sánchez 1991, Biber 1993, Sánchez and Rodríguez 1994, Sánchez 2003). However, doubtless the loss of habitat due to the drainage of wetlands or the regulation of river systems in the breeding and wintering areas (Reichholf 1989) has been the fundamental cause of the decline of many populations, examples being those of northern and eastern Europe (Møller 1975d, Biber 1993, Cherninchko 1993). This transformation of habitat has also been a determinant in the species' feeding (Siokhin 1993, Rudenko 1996), since in many areas pasture, in which they previously fed on insects, has been converted to crop-land. There has been an additional collateral negative impact on the species in this conversion, since there 
seems to have been a major effect of pesticides in reducing the colony size of some populations (Biber 1993, Fasola and Canova 1996, Cherninchko 1993, Sánchez and Fasola, 2002).

Furthermore, colonies are affected by numerous predators. Some are terrestrial, such as foxes or stray dogs that may enter a colony when a fall in water level connects the islets to the shore (Sánchez and Rodríguez 1994). Others are birds, both diurnal (Lévêque 1955, 1957, Rudenko 1996) and nocturnal such as Barn Owl Tyto alba or Short-eared Owl Asio flammeus (Sánchez, 2003). In some cases, predation is by rats, because, although in many cases the species inhabits areas with no vegetation, its preference is for islets with vegetation (Goutner 1987, Sánchez et al. 1991) in which there may be large rodent populations. Moreover, in mixed-species colonies, gulls such as Yellow-legged Gull Larus cachinans and Black-headed Gull L. ridibundus may prey on the chicks and eggs (Møller 1975b, Sánchez and Blasco 1987), and other terns of a similar size, such as Sandwich Tern Sterna sandvicensis may also have a negative influence (Siokhin 1993).

\section{Acknowledgements}

The helpful comments of J. P. Biber and S. Delany improved the original manuscript. During the study C. Corbacho, E. Costillo and C. Fuentes had a grant from the Convenio Confederación Hidrográfica del Guadiana and Universidad de Extremadura.

\section{References}

Balzac, H. and Mayaud, N. (1962) Les Oiseaux du Nord-Ouest de l'Afrique. Paris: Lechevalier. Berndt, R. K. and Busche, G. (1993) Vogelwelt Schleswig-Holsteins-Band 4, Entenvögel II, Wachholtz, Neumünster, $228 \mathrm{~S}$.

Biber, J. P. (1993) Status and distribution of the gull-billed tern (Sterna nilotica) in the Western Palearctic. In J. S. Aguilar, X. Monbailliu and A. M. Paterson, eds. Status and conservation of seabirds. Madrid: Sociedad Española de Ornitología.

Boutin, J., Cherain, Y. and Pambour, B. (1987) Compte rendu ornithologique camaguais pour les années 1984-1985. Rev. Ecol. (Terre et Vie) 42: 167-191.

Brichetti, P. and Cherubini, G. (1996) Popolazioni di ucelli acquatici nidificanti in Italia. Situazione 1996. Avocetta 20: 85-86.

Brichetti, P. and Cherubini, G. (1997) Popolazioni di ucelli acquatici nidificanti in Italia (Sitauzione 1996). Avocetta 21: 218-219.

Brichetti, P. and Foschi, U. (1985) Valli di Comacchio: situazione Laridae e Sternidae 1985. Riv. Ital. Orn. 55(3-4): 185-186.

Brichetti, P. and Foschi, U. (1988) Valli di Comacchio: situazione Laridae e Sternidae 19871988. Riv. Ital. Orn. 55(3-4): 211-212.

Brichetti, P. and Foschi, U. (1986) Valli di Comacchio: situazione Laridae e Sternidae 1986. Riv. Ital. Orn. 56(3-4): 249-250.

Brichetti, P., Cherubini, G. and Serra, L. (2000) Popolazioni di ucelli acquatici nidificanti in Italia: situazione 1997 e 1998. Avocetta 24: 55-57.

Cabo, J. M. and Sánchez, J. M. (1984) Nouvelles donnés sur Gelochelidon nilotica au Maroc et sur son regime alimentaire. Alauda 54(3): 207-212.

Carmena, A. and Pereira, P. (1981) Avifauna nidificante en la laguna de Manjavacas (Cuenca). Alytes 1: 159-170. 
Cherninchko, I. (1993) Breeding population and distribution of seabirds (gulls and terns) on the northern coast of the Black Sea and Sea of Azov. In J. S. Aguilar, X. Monbailliu and A. M. Paterson, eds. Status and conservation of seabirds. Madrid: Sociedad Española de Ornitología.

Costa, L. (1986) Alimentación de la Pagaza piconegra (Gelochelidon nilotica) en las marismas del Guadalquivir. Doñana Acta Vertebrata 11(29): 185-195.

Costa, M. (1997) La comunita di Caradriformi nidificanti nella palude dell'Ortazzo (Ravenna) nella stagione riproduttiva 1996. Quad. Stud. Nat. Romagna 7: 75-79.

Cramp, S. and Simmons, K. E. L. (1985) Birds of the Western Palearctic. Volume 4. London: Oxford University Press.

Delany, S., Reyes, C., Hubert, E., Pihl, S., Rees, E., Haanstra, L., and van Strien, A. (1999) Results from the international waterbird census in the Western Paleartic and Southwest Asia 1995 and 1996. Wageningen, The Netherlands: Wetlands International.

Dodman, T. and Taylor, V. (1995) African waterfowl census 1995. Les Dénombrements Internationaux d'eau en Afrique, 1996. Slimbridge. U.K.: IWRB.

Dodman, T. and Taylor, V. (1996) African waterfowl census 1996. Les Dénombrements Internationaux d'eau en Afrique, 1996. Wageningen, The Netherlands: Wetlands International.

Dodman., T., Vaan, C. de, Hubert, E. and Nivet C. (1997) African waterfowl census 1997. Les Dénombrements Internationaux d'eau en Afrique, 1997. Wageningen, The Netherlands: Wetlands International.

Fasola, M. and Canova, L. (1996) Conservation of gull and tern in Northeastern Italy, an internationally Important Bird Area. Colonial Waterbirds 19 (Special Publ. 1): 59-67.

Fasola, M., Goutner, V. and Walmsley, J. (1993) Comparative breeding biology of the gulls and terns in the four main deltas of the northern Mediterranean. In J. S. Aguilar, X. Monbailliu and A. M. Paterson, eds. Status and conservation of seabirds. Madrid: Sociedad Española de Ornitología.

Foschi, U. (1986) Distribuzione e popolazione dei Laridi e Sternidi nidificanti in Italia. Suplemento Ricerche Biologia della Selvaggina XI: 73-81.

Francois, J. (1975) L'avifaune annuelle au lac de Boughzoul (Algerie). Alauda 43: 125-133.

Glutz, V. and Bauer, K. M. (1982) Handbuch der Voegel Mitteleuropas. Volume 8/II. Wiesbaden: Akademische Verlagsgesellschaft.

Goutner, V. (1987) Vegetation preferences by colonies of Mediterranean Gulls (Larus melanocephalus) and Gull-billed Terns (Gelochelidon nilotica) in the Evros delta. Seevögel 8(2): $29-31$.

Goutner, V. (1991) Food and feeding ecology of gull-billed terns (Gelochelidon nilotica) in Greece. Rev. Ecol. (Terre et Vie) 46: 373-383.

Goutner, V. and Kattoulas, M. (1984) Breeding distribution of Gulls and Terns (Laridae, Sternidae) in the Evros delta (Greece). Seevögel 5: 40-41.

Goutner, V. and Papakostas, G. (1992) Evaluation of the ornithological importance of the Alyky Kitrous wetland, Macedonia, Greece: a priority for conservation. Biol. Conserv. 62: $131-138$.

Hagemeijer, E. J. M. and Blair, M. J. (eds.) (1997). The EBCC atlas of European breeding birds: their distribution and abundance. London: T. and A. D. Poyser.

Johnson, A. R. and Isennman, P. (1971) L'evolution des effectifs nicheurs laro-limicoles en zone saumatres de Camargue. Alauda 39: 29-36.

Keve, A. (1960) Magyarorzag Madarainak Nevjegyzeke. Nomenclator avium Hungariae, Budapest: A. Madartani Intezet Kiadvanya.

Lamani, F. and Puzanov, V. (1962) Inventari i shpendeve te Squiperie. Bul. Univ. Trivanes. Ser. Shk. Nat. 3: 87-103.

Latour, M. (1973) Nidification de 5 espéces de Laridés dans l'embouchure du Senegal. Oiseau et R.F.O. 43: 89-96. 
Le Berre, M. and Rostan, J. C. (1976) Inventaire de l'avifaune d'une zone de mise en valeur agricole dans le Constantinois. Bull. Soc. Hist. Nat. Afr. Nord [1976]: 243-270.

Lévêque, R. (1955) Une colonie de Sternes hansel en Camargue. Nos Oiseaux 23: 233-246.

Lévêque, R. (1957) L'avifaune nidificatrice des eaux saumatres de Camargue en 1956, essai de denobrement suivi d'une esquisse écologique. Rev. Ecol. (Terre et Vie) 11: 150-178.

Magnin, G. and Yarar, M. (1997) Important Bird Areas in Turkey. Istanbul: Dogal Hayati Koruma Dernegi.

Maluquer, S. (1971) Las aves del Delta del Ebro en primavera-verano. Ardeola 1971: 191-334.

Maluquer, S. and Pons, J. R. (1961) La avifauna de la isla de Buda en primavera-verano de 1961. Ardeola 7: 79-111.

Martínez-Villalta, A. (1991) Primer censo nacional de larolimícolas coloniales y Pagaza piconegra. Ecología 5: 321-327.

Mayaud, N. (1983) Les oiseaux du Nord-ouest de l'Afrique. Notes complementaires. Alauda 51: 271-301.

Metzmacher, M. (1976) Contribution à l'ornithologie de l'est oranais. Bull. Soc. geogr. archél. D'Oran 1976: 66-76.

Møller, A. P. (1975a) Ynglebestanden af Sandterne Gelochelidon n. nilotica Gmel. i 1972 i Europa, Afrika og Vestasien, med et tilbageblik over bestandsaendringer i dette arhundrede. Dan. Ornithol. Foren. Tidsskr. 69: 1-8.

Møller, A. P. (1975b) Sandternens Gelochelidon n. nilotica Gm. ynglebiologi i Danmark. Dan. Ornithol. Foren. Tidsskr. 69: 9-18.

Møller, A. P. (1975c) Sandternens Gelochelidon n. nilotica Gm sorn ynglefugl i Denmark. Dansk Fugle 27: 33-43.

Møller, A. P. (1975d) Sandterns Gelochelidon n. nilotica Gmel. bestandsaendringer i Danmark og analyse af nogle bestandsregulerende faktorer. Dansk Orn. Foren. Tidsskr. 69: 81-88.

Møller, A. P. (1975e) Migration of European Gull-billed Terns (Gelochelidon n. nilotica) according to recoveries. Danske Fugle 27: 61-77.

Møller, A. P. (1977) Sandternens Gelochelidon n. nilotica Gmel. fode i yngletiden i Nordjylland og Camargue, Frankrig, med en oversigt over fodeemner i andre dele af artens udbredelsesomrade. Dan. Ornithol. Foren. Tidsskr. 71: 103-111.

Nankinov, D. (1993) Status and conservation of breeding seabirds in Bulgaria. In J. S. Aguilar, X. Monbailliu and A. M. Paterson, eds. Status and conservation of seabirds. Madrid: Sociedad Española de Ornitología.

Naurois, R. (1959) Premiers recherches sur l'avifaune des iles du Banc d'Arguin (Mauritane). Alauda 27: 241-308.

Otero-Muerza, C. (1980) Contribución al conocimiento de las lagunas de alcazar de San Juan. Boletín Estación Central de Ecología 9(18): 63-79.

Perennou, C. (1992) African waterfowl census 1992. Les Dénombrements International d'eau en Afrique, 1997. Slimbridge. U.K.: IWRB.

Reichholf, J. H. (1989) Warum verschwanden Lachseeschwalbe Gelochelidon nilotica und Triel Burhines oedicnemus als Brutvögel aus Bayern? Anz. Orn. Ges. Bayern 28(1): 1-14.

Rendón, M. (2001) Informe de la avifauna reproductora en la Laguna de Fuentepiedra (Málaga). Spain: Fuentepiedra.

Robin, P. (1968) L'avifaune de l'Iriki (Sud-Marocain). Alauda 36: 237-253.

Rose, P. (1992) Western Palearctic waterfowl census 1992. Slimbridge, U.K.

Rose, P. M. and Scott, D. A. (1994) Waterfowl population estimates. Slimbridge, U.K.: IWRB (Special publ. 29).

Rose, P. M. and Scott, D. A. (1997) Waterfowl populations estimates. Second edition. Wageningen, The Netherlands: Wetlands International (Publ. 44). 
Rose, P. and Taylor, V. (1993) Western Palearctic and South West Asia waterfowl census 1993. Les Dénombrements Internationaux d'eau en Afrique, 1996. Slimbridge, U.K.: IWRB.

Rudenko, A. G. (1996) Present status of gulls and terns nesting in the Black Sea Biosphere Reserve. Colonial Waterbird 19 (Special Publ. 1): 41-45.

Sadoul, N. and Isenmann, P. (1999) Sterne hansel. Pp. 246-247 in G. Rocamora and D. Yeatman-Berthelot, eds. Oiseaux menaces et à surveiller en France. Paris: Société d'Etudes ornithologiques de France.

Sadoul, N., Johnson, A. R., Walmsley, J. G. and Leveque, R. (1996) Changes in the numbers and distribution of colonial Charadriformes breeding in the Camarga, Southern France. Colonial Waterbirds 19 (Special Publ.1): 46-68.

Sánchez, J. M. (1984) Contribución al conocimiento de la Biología y Desarrollo de Gelochelidon n. nilotica. Unpublished Ph.D. thesis. Universidad de Málaga.

Sánchez, J. M. (2003) Gelochelidon nilotica. In R. Martin and J. C. del Moral, eds. Atlas de las aves reproductoras de España. Madrid: Dirección General de Conservación de la Naturaleza-Sociedad Española de Ornitología.

Sánchez, J. M. and Blasco, M. (1987) Biología reproductora de Gelochelidon nilotica (Gm., 1789) en el Sur de la Península Ibérica. Misc. Zool. 10: 259-266.

Sánchez, J. M. and Fasola, M. (2002) Gelochelidon nilotica. BWP Update 4(1):21-33.

Sánchez, J. M. and Mañez, M. (in press) Gelochelidon nilotica. Libro Rojo de las Aves de España. Madrid: Ministerio de Medio Ambiente.

Sánchez, J. M. and Muñoz, A. (1997) Gelochelidon nilotica. In Atlas de las Aves de España (1975-1995). Barcelona: Lynx Edicions.

Sánchez J. M. and Sánchez, A. (1991) La reproducción de la Pagaza piconegra Gelochelidon nilotica en las Vegas Altas del Guadiana en la primavera de 1989. Ardeola 38: 131-135.

Sánchez, J. M. and Rodríguez, J. A. (1994) Measures to correct the impact on aquatic birds caused by the operation Orellana reservoir, Extremadura, Spain. Pp. 255-272 in XVII International Congress on Large Dams. Volume II. Durban: CIGB-ICOLD.

Sánchez, J. M., Muñoz del Viejo, A. and Cruz, C. de La (1991) Relación entre la cobertura vegetal y la distribución de nidos en las colonias de Pagaza piconegra. Doñana Acta Vertebrata 18: 152-158.

Schlenker, R. (1966) Über das Vorkommen der Lachseeschwalbe, Gelochelidon nilotica (Gmel.), an der Westküste Schleswig-Holstein. Corax 1: 209-216.

Serra, L. and Brichetti, P. (2000) Ucelli acquatici nidificanti: 1999. Avocetta 24: 133-138.

Siokhin, V. (1993) Factors influencing the population structure and trophic levels in the main breeding colonies of gulls and terns in Black and Azov Seas. Pp. 229-237 in J. S. Aguilar, X. Monbailliu and A. M. Paterson, eds. Status and conservation of seabirds. Madrid: Sociedad Española de Ornitología.

Taczanowski, L. (1870). Übersicht der Vögel die in Algerien, Provinz Constantine, während der Reise von Ende November 1866 bis Ende April 1867, gesammelt und beobachtet werden. J. Orn. 12: 33-56.

Trotignon, J. (1976) La nidification sur le Banc d'Arguin (Mauritanie) au printemps 1974. Alauda 44: 119-133.

Tucker, G. M. and Heath, M. F. (1994). Birds in Europe: their conservation status. Cambridge, U.K.: BirdLife International.

Unión Mundial para la Naturaleza (UICN) (1994) Categorías de las Listas Rojas de la UICN.

Vargas, J. M., Antunez, A. and Blasco, M. (1978) Comportamiento reproductor y alimentario de Gelochelidon nilotica en la Laguna de Fuente Piedra. Ardeola 24: 227-231.

Wetlands International (2002) Waterbird populations estimates. Third edition. Wageningen, The Netherlands: Wetlands International (Global series 12).

White, G. C. and Garrott, R. A. (1990) Analysis of radio-tracking data. Academic Press Inc: New York, USA. 
J. M. SÁNCHEZ* A. MUÑOZ DEL VIEJO, C, CORBACHO E. COSTILLO and C. FUENTES Grupo de Investigación en Conservación, Área de Zoología, Universidad de Extremadura, Avenida de Elvas, s/n Badajoz, Spain

*Author for correspondence. E-mail: jsanchez@unex.es

Received 12 May 2003; revision accepted 24 June 2004 


\section{Appendix. Places where the Gull-billed Tern has bred in the period covered by the study}

Boldface underlined indicates places where stable colonies exist. Non-boldface indicates places where unstable colonies exist, with frequent or regular (underlined) or only sporadic (non-underlined) breeding attempts occur.

\section{DENMARK}

1. West Jutland (6) (Møller 1975a-e)

NETHERLANDS

1a. Rotterdam (Biber 1993, Møller 1975a)

\section{GERMANY}

2. Baden-Württemberg (Møller 1975a)

3. Bayer (Cramp and Simmons 1985)

4. Schleswig-Holstein (Glutz and Bauer 1982, Biber 1993 Berndt and Buche 1993, Schlenker 1966)

\section{FRANCE}

5. Rhône mouth (4) (Boutin et al. 1987, Biber 1993, Johnson and Isenmann 1971, Sadoul and Isenmann 1999, Leveque 1955, 1957, Boutin et al. 1987, Fasola et al. 1993)

\section{SPAIN}

6. Ebro Delta (3) (Maluquer and Pons 1961, Maluquer 1971, Martínez-Villalta 1991, Fasola et al. 1993)

7. Gallocanta Pool (Martínez-Villalta 1991)

8. Villafranca Pool (Martínez-Villalta 1991)

9. Manjavacas Pool (Carmena and Pereira 1981, Martínez-Villalta 1991)

10. Longar de Lillo Pool (Martínez-Villalta 1991)

11. Albardiosa Pool (Martínez-Villalta 1991)

12. Quero Saline (Martínez-Villalta 1991)

13. Pétrola Pool (Martínez-Villalta 1991).

14. Alcazar de San Juan Pool (Otero-Muerza 1980)

15. Valdecañas Reservoir (Martínez-Villalta 1991)

16. Orellana Reservoir (Martínez-Villalta 1991,

Sánchez and Sánchez 1991)

17. Sierra Brava Reservoir (own data)

18. Casas de Hito Pool (own data)

19. Gorbea Pool (own data)

20. Arroyo-Conejo Reservoir (own data)

21. Alange Reservoir (own data)

22. Los Canchales Reservoir (own data)

23. Guadalquivir Marshes (3) (Costa 1986, Martínez-Villalta 1991, Sánchez and Máñez in press)

24. Fuentepiedra Pool (Martínez-Villalta 1991, Vargas et al. 1978, Sánchez and Blasco 1987, Rendón 2001)

25. Laguna de Villafáfila (Martínez-Villalta 1991)
ITALY

26. Comacchio Valley (Brichetti and Foschi 1985, 1986, 1988, Foschi 1986, Fassola et al. 1993, Brichetti and Cherubini 1996, 1997, Brichetti et al. 2000, Serra and Brichetti 2000)

27. Manfredonia Gulf (Foschi 1986, Brichetti and Cherubini 1996, 1997, Brichetti et al. 2000, Serra and Brichetti 2000)

28. Salin de Cagliari (Sardinia) (Foschi 1986)

29. Salin de Cervia (Brichetti and Cherubini 1996)

30. Biviere de Lentini (Brichetti and Cherubini 1996)

31. Foce Bevano (Brichetti and Cherubini 1997, Brichetti et al. 2000)

32. Province Oristano (Brichetti and Cherubini 1996, Brichetti et al. 1998)

33. Lagune Venezia (Brichetti and Cherubini 1997, Brichetti et al. 2000, Serra and Brichetti 2000)

34. Stagno de Molentargius (Brichetti et al. 200o, Serra and Brichetti 200o)

35. Pialasse y Valli Ravennati (Brichetti and Foschi 1986, Costa 1997)

\section{GREECE}

36. Evros Delta (Goutner and Kattoulas 1984, Fasola et al. 1993)

37. Nestos Delta (Cramp and Simmons 1985)

38. Alyky (Goutner and Papakostas 1992)

39. Messologhi (Goutner 1991)

\section{BULGARIA}

40. Atanosoo Lake (Nankinov 1993)

41. Burgas Lake (Nankinov 1993)

42. Madresko Lake (Nankinov 1993)

43. Dourankulak (Nankinov 1993)

44. Batova River (Nankinov 1993)

45. Western Sofia Marshes (Nankinov 1993)

46. Danube River islands (Nankinov 1993)

ROMANIA

47. Danube Delta (Dobrogea) (Biber 1993)

HUNGARY

48. Fertö Lake (Glutz and Bauer 1982)

49. Balaton Lake (Glutz and Bauer 1982)

50. Neusiedlersee Coast (Keve 1960)

YUGOSLAVIA

51. Montenegro (Biber 1993) 
ALBANIA

52. Durazzo Lake (Lamani and Puzanov 1962)

BLACK SEA AND AZOV SEA (8)

53. Danube mouth until Ukraine

54. Tendra Gulf islands (Cramp and Simmons 1985)

55. Kartinitsky Gulf (Cherninchko 1993)

56. Sivash Land (Cherninchko 1993, Siokhin 1993)

\section{ALGERIA}

57. Fetzara Lake (Balzac and Mayaud 1962)

58. Zana Marshes (Taczanowski 1870)

59. Boughzoul Lake (François 1975)

6o. Bou-Lhilet (Le Berre and Rostan 1976)

61. La Macta (Metzmacher 1976)

TUNISIA

62. Tunis Lake (Cramp and Simmons 1985) 63. Sebkha El Djem (Mayaud 1983)
MOROCCO

64. Afsó Pool (Cabo and Sanchez 1984)

65. L'iriki (Mayaud 1983)

MAURITANIA

66. Banc d'Arguin (Naurois 1959)

SENEGAL

67. Senegal River (Latour 1973)

TURKEY (Magnin and Yarar 1997)

68. Isikli Gölü

69. Acigol

70. Aksehir E Eber Gölü

71. Sultansazligi

72. Seyke Gölü

73. Hirfanli Baraji

74. Samsam Gölü

75. Kozanli Gökgöl

76. Kulu Gölü

77. Bolluk Gölü

78. Bulanik Ovasi 